\title{
HUBUNGAN POLA MAKAN DENGAN KEJADIAN ANEMIA DI PONDOK PESANTREN AL MAS'UDIYAH PUTERI 2 BLETER KABUPATEN SEMARANG TAHUN 2019
}

\author{
Rabia Wahdah ${ }^{1}$ Heni Setyowati ${ }^{2,}$ Eti Salafas $^{3}$ \\ Program Studi D IV Kebidanan Universitas Ngudi Waluyo, Ungaran \\ Email : rabiawahdah04@gmail.com
}

\begin{abstract}
ABSTRAK
Asupan pola makan yang tidak sesuai dengan pola makan seimbang menyebabkan ketidakseimbangan antara asupan dan kecukupan gizi yang dibutuhkan tubuh terutama zat gizi yang pembentuk sel darah merah. Jumlah asupan yang rendah menyebabkan pembentukan sel darah merah menurun sehingga terjadi anemia. Data World Health Organization (WHO) menunjukkan sekitar 25-40\% remaja puteri menjadi penderita anemia. Sedangkan kejadian anemia pada kelompok usia remaja di Jawa Tengah Tahun 2014 sebanyak 26,5\%. Mengetahui hubungan pola makan dengan kejadian anemia di Pondok Pesantren Al Mas'udiyah Puteri 2 Bleter Kabupaten Semarang. Desain penelitian yaitu deskriptif korelasi dengan pendekatan secara cross sectional. Populasi dalam penelitian ini yaitu seluruh santriwati Pondok Pesantren Al Mas'udiyah Puteri 2 Bleter Kabupaten Semarang, teknik sampling menggunakan simple random sampling. Teknik analisis data yang digunakan adalah uji kendall's tau. Berdasarkan uji kendall's tau nilai p-value sebesar $0,001(<0,05)$ artinya terdapat hubungan yang signifikan antara pola makan dengan kejadian anemia di pondok pesantren Al Mas'udiyah Puteri 2 Bleter Kabupaten Semarang. Ada hubungan antara pola makan dengan kejadian anemia di pondok pesantren Al Mas'udiyah Puteri 2 Bleter Kabupaten Semarang.
\end{abstract}

Kata kunci : Pola Makan, Anemia, Remaja.

\section{ABSTRACT}

The Relationship Of Eating Patterns With The Event Of Anemia In Pondok Pesantren Al Mas'udiyah Puteri 2 Bleter Semarang District, 2019

The intake of a diet if not in accordance with a balanced diet causes an imbalance between the intake and adequacy of nutrients the body needs, especially nutrient that make up red blood cells. The low amount of intake causes the formation of red blood cells to decrease so that anemia occurs. Data from the World Health Organization (WHO) shows that around 25-40\%. To find out the relationship between diet and anemia in Al Mas'udiyah islamic boarding school semarang district. The methode of research design in descriptive correlationwith a cross sectioan approach. The population is all student of Al Mas'udiyah islamic boarding school semarang district, the sampling technique used was simple random sampling. The data analysis technique used is the kendall's tau test. Based on the kendall's tau test, the p-value of 0.001 $(<0.05)$ means that there is a significant relationship between eating patterns and anemia in Al Mas'udiyah islamic boarding school semarang district. There is a correlation between dietary habbit and anemia in Al Mas'udiyah islamic boarding school semarang district. 
Keyword : Dietary Habbit, Anemia, Teenager.

\section{PENDAHULUAN}

Remaja yang dalam bahasa aslinya disebut adolescence, berasal dari bahasa Latin adolescare yang artinya "tumbuh atau tumbuh untuk mencapai kematangan". Masa remaja merupakan masa perubahan yang dramatis, pertumbuhan pada usia anak-anak relatif terjadi dengan kecepatan yang sama dialami oleh pertumbuhan remaja, peningkatan pertumbuhan yang disertai perubahan hormonal, kognitif, dan emosional. Semua masa perubahan ini membutuhkan zat gizi secara khusus (Ari Istiany, 2013). Menurut World Health Organization (WHO), remaja adalah individu baik perempuan maupun laki-laki yang berada pada usia antara anak-anak dan dewasa. Batasan remaja dalam hal ini adalah usia 10 sampai 19 tahun. Usia 10 sampai 15 tahun, dikenal dengan masa pertumbuhan cepat (growth spurt), merupakan tahap pertama dari serangkaian perubahan menuju kematangan fisik dan seksual.

Anak-anak dan wanita usia subur (WUS) adalah kelompok yang paling berisiko, dengan perkiraan prevalensi anemia pada balita sebesar $47 \%$, pada wanita hamil sebesar $42 \%$, dan pada wanita yang tidak hamil usia 15-49 tahun sebesar $30 \%$. World Health Organization (WHO) menargetkan penurunan prevalensi anemia pada WUS sebesar $50 \%$ pada tahun 2025. Anemia merupakan masalah gizi di dunia, terutama di negara berkembang termasuk Indonesia. Angka anemia gizi besi di Indonesia sebanyak $72,3 \%$. Anemia adalah suatu kondisi tubuh dimana kadar hemoglobin (Hb) dalam darah lebih rendah dari normal (WHO, 2011).

Sampai saat ini, anemia masih menjadi salah satu masalah kesehatan terbesar yang dialami oleh semua kelompok umur terutama remaja. Masa remaja adalah masa transisi dari tahap anak-anak ke tahap dewasa yang membutuhkan zat gizi lebih tinggi termasuk zat besi (Sediaoetama, 2008).

Menurut World Health

Organization WHO (2013) prevalensi anemia dunia berkisar 40-88\%. Sedangkan di Asia Tenggara, World Health Organization (WHO) Regional Office South East Asia Region Organisation (SEARO) menyatakan bahwa $25-40 \%$ remaja putri menjadi penderita anemia defisiensi zat besi tingkat ringan sampai berat (Tim Poltekkes Depkes Jakarta I, 2010). Di Indonesia, data kemenkes (2013) mengatakan bahwa prevalensi anemia pada kelompok usia remaja $\geq 15$ tahun sebesar 22,7\%, Provinsi Jawa Tengah sendiri, prevalensi anemia gizi besi pada wanita sebesar 26,5\% (Depkes Prov Jateng, 2014).

Kekurangan zat besi pada remaja mengakibatkan pucat, lemah, letih, pusing, dan menurunnya konsentrasi belajar dan berdampak pada menurunnya ketahanan fisik, kapasitas kerja, mempengaruhi fungsi kognitif seperti konsentrasi belajar rendah dan memperlambat daya tangkap (Isniati, 2007). Selain itu menurut penelitian Dumilah (2017) anemia menyebabkan daya konsentrasi rendah dan berdampak pada prestasi belajar menjadi kurang optimal atau rendah. Akibat jangka panjang apabila remaja putri hamil maka ia tidak akan mampu memenuhi zat gizi bagi dirinya dan janin. Anemia dapat meningkatkan frekuensi komplikasi, risiko kematian maternal, angka prematuritas, BBLR, dan angka kematian perinatal (Hayati, 2010). Pada saat akan menjadi calon ibu maka akan menjadi calon ibu yang beresiko tinggi untuk kehamilan dan melahirkan, dampak anemia pada ibu hamil 
$\begin{array}{lcr}\text { diantaranya } & \text { perdarahan } & \text { waktu } \\ \text { melahirkan } & \text { sehingga } & \text { dapat } \\ \text { menyebabkan } & \text { kematian } & \text { ibu }\end{array}$

(Sulistyoningsih, 2011).

Timbulnya anemia dapat disebabkan oleh asupan pola makan yang salah, tidak teratur dan tidak seimbang dengan kecukupan sumber gizi yang dibutuhkan tubuh diantaranya adalah asupan energi, asupan protein, asupan karbohidrat, asupan lemak, vitamin $\mathrm{C}$ dan yang terutama kurangnya sumber makanan yang mengandung zat besi, dan asam folat. Aktifitas sekolah, perkuliahan maupun berbagai aktifitas organisasi dan ekstrakurikuler yang tinggi akan berdampak pada pola makan yang tidak teratur, selain itu kebiasaan mengkonsumsi minuman yang menghambat absorbsi zat besi akan mempengaruhi kadar hemoglobin seseorang (Dinkes, 2012).

Studi pendahuluan yang dilakukan di Pondok Pesantren Al'Masudiyah putri 2 Bleter Kab. Semarang pada tahun 2019, dari 450 santriwati putri, peneliti melakukan studi pendahuluan dengan wawancara dan pemeriksaan kadar hemoglobin kepada 10 santriwati, didapatkan 8 orang $(80 \%)$ remaja mengalami anemia. Hasil wawancara dari 10 (100\%) tidak mengetahui tentang penyebab anemia, kadar normal hemoglobin, makanan yang mengandung zat besi, dampak anemia dan terapi anemia. Belum pernah ada penyuluhan yang dikhususkan tentang anemia, dan belum pernah ada pemeriksaan kadar hemoglobin di Pondok Pesantren ini.

\section{Tujuan Penelitian}

Tujuan Umum

Penelitian ini bertujuan untuk mengetahui hubungan pola makan dengan kejadian anemia pada remaja di Pondok Pesantren Al'Masudiyah putri 2 Bleter.

\section{Tujuan Khusus}

1. Mengetahui gambaran pola makan pada remaja putri di Pondok Pesantren Al'Masudiyah putri 2 Bleter

2. Mengetahui gambaran kejadian anemia pada Remaja putri di Pondok Pesantren Al'Masudiyah putri 2 Bleter

3. Menganalisis hubungan antara pola makan dengan kejadian anemia pada remaja putri di Pondok Pesantren Al'Masudiyah putri 2 Bleter.

\section{METODE}

Penelitin ini menggunakan desain penelitian deskriptif korelasi dengan pendekatan cross sectional. Penelitian ini dilakukan di Pondok Pesantren Al Mas'udiyyah Puteri 2 Bleter Kabupaten Semarangpada bulan Mei 2019. Populasi dalam penelitian ini adalah 450 siswi di Pondok Pesantren Al Mas'udiyyah Puteri 2 Bleter Kabupaten Semarang. Sampeldalam penelitian ini sebanyak 82 responden.Tehnik pengambilan sampel untuk penelitian ini menggunakan simple random sampling.Teknis analisis data yang digunakan adalah uji kendall's tau. Pengukuran variabel asupan pola makan menggunakan food recall 24 hoursselama 2 hari dan sedangkan pemeriksaan kadar hemoglobin menggunakan haemometer digital (family doc) yang dilakukan satu kali pada satu waktu.

\section{HASIL PENELITIAN DAN PEMBAHASAN}

Analisis Univariat

Dalam penelitian ini analisis univariat digunakan untuk memberikan gambaran tentang pola makan dan status anemia pada santriwati Pondok Pesantren Al masudiyah Puteri 2 Bleter Kabupaten Semarang. 
Tabel 1. Distribusi frekuensi pola makan pada santriwati Pondok Pesantren Al masudiyah Puteri 2 Bleter Kabupaten Semarang.

\begin{tabular}{lll}
\hline Pola Makan & Frekuensi & Persentase (\%) \\
\hline Normal & 23 & 28 \\
Defisit ringan & 47 & 57.3 \\
Defisit berat & 10 & 12.2 \\
Berlebih & 2 & 2.4 \\
\hline
\end{tabular}

Total 8

Tabel 1 menunjukkan bahwa sebagian besar pola makan responden dalam kategori defisit ringan sebanyak 47 responden $(57,3 \%)$, responden dalam kategori kategori normal sebanyak 23 responden $(28 \%)$, defisit berat sebanyak 10 responden $(12,2 \%)$, dan berlebih sebanyak 2 responden $(2,4 \%)$.

Banyaknya santriwati yang masuk dalam kategori pola makan defisit ringan adalah akibat dari makanan yang dikonsumsi individu dalam satu hari tidak beraneka ragam dan tidak mengandung zat tenaga, zat pembangun, dan zat pengatur sesuai dengan kebutuhan tubuhnya. Berdasarkan hasil penelitian didapatkan bahwa jumlah konsumsi karbohidrat merupakan jumlah konsumsi paling rendah diantara zat gizi lainnya yaitu 1484 kkal. Padahal menurut Almatsier (2011) karbohidrat merupakan sumber energi utama tubuh yang tersusun dari unsur Carbon (C), Hidrogen $(\mathrm{H})$, dan Oksigen (O). Selain itu, mengkonsumsi pangan pokok, pangan hewani, sayur dan buah dalam jumlah yang tidak memadai, akan berimplikasi pada tidak terpenuhinya kebutuhan energi, protein dan berbagai mineral yang penting bagi tubuh seperti besi, iodium dan zink yang kaya dalam pangan hewani, serta vitamin utamanya vitamin $\mathrm{A}, \mathrm{C}$ dan asam folat yang banyak terkandung pada buah dan sayur. Mayoritas responden dalam penelitian ini mengkonsumsi susu dan teh pada saat pagi hari sebelum pergi ke kekelas
100.0

padahal menurut hasil penelitian Balci (2012) makanan yang dapat menghambat penyerapan zat besi yaitu kopi, coklat, teh dan kopi mengandung tanin yang dapat menghambat absorpsi zat besi. Susu juga merupakan pangan sumber protein yang baik yang memiliki bioavailabilitas tinggi.Protein yang terkandung di dalamnya berperan dalam distribusi zat gizi termasuk distribusi zat besi. Namun susu juga mengandung kalsium yang tinggi yang dapat menghambat penyeraban zat besi (Briawan, 2011). Asupan energi dalam penelitian ini menempati posisi tertinggi yaitu $13450 \mathrm{Kkal}$ yang paling banyak dikonsumsi oleh responden yang anemia, padahal energi sangat baik sebagai zat pembangun akan tetapi daya absorbsi zat besi dari pangan karbohidrat yang diperoleh seagai sumber energi termasuk rendah sehingga tidak memberikan sumbangan zat besi dalam jumlah yang banyak (Misterianingtyas, 2009). Kekurangan konsumsi energi dapat menyebabkan anemi, hal ini terjadi karena pemecahan protein tidak lagi ditujukan untuk pembentukan sel darah merah dengan sendirinya menjadi kurang sehingga pemecahan protein energi dapat menyebabkan ketidakseimbangan dalam tubuh (Nursari 2010).

\section{HASIL PENELITIAN DAN PEMBAHASAN}

Analisis Univariat

Dalam penelitian ini analisis univariat digunakan untuk memberikan gambaran tentang pola makan dan 
status anemia pada santriwati Pondok Pesantren Al masudiyah Puteri 2 Bleter Kabupaten Semarang.
Tabel 2. Distribusi frekuensi pola makan pada santriwati Pondok

Pesantren Al masudiyah Puteri 2 Bleter Kabupaten Semarang.

\begin{tabular}{lcc}
\hline Pola Makan & Frekuensi & Persentase (\%) \\
\hline Normal & 23 & 28 \\
Defisit ringan & 47 & 57.3 \\
Defisit berat & 10 & 12.2 \\
Berlebih & 2 & 2.4 \\
\hline
\end{tabular}

\section{Total}

Tabel 2 menunjukkan bahwa sebagian besar pola makan responden dalam kategori defisit ringan sebanyak 47 responden $(57,3 \%)$, responden dalam kategori kategori normal sebanyak 23 responden $(28 \%)$, defisit berat sebanyak 10 responden $(12,2 \%)$, dan berlebih sebanyak 2 responden $(2,4 \%)$.

Banyaknya santriwati yang masuk dalam kategori pola makan defisit ringan adalah akibat dari makanan yang dikonsumsi individu dalam satu hari tidak beraneka ragam dan tidak mengandung zat tenaga, zat pembangun, dan zat pengatur sesuai dengan kebutuhan tubuhnya. Berdasarkan hasil penelitian didapatkan bahwa jumlah konsumsi karbohidrat merupakan jumlah konsumsi paling rendah diantara zat gizi lainnya yaitu 1484 kkal. Padahal menurut Almatsier (2011) karbohidrat merupakan sumber energi utama tubuh yang tersusun dari unsur Carbon $(\mathrm{C})$, Hidrogen $(\mathrm{H})$, dan Oksigen (O). Selain itu, mengkonsumsi pangan pokok, pangan hewani, sayur dan buah dalam jumlah yang tidak memadai, akan berimplikasi pada tidak terpenuhinya kebutuhan energi, protein dan berbagai mineral yang penting bagi tubuh seperti besi, iodium dan zink yang kaya dalam pangan hewani, serta vitamin utamanya vitamin $\mathrm{A}, \mathrm{C}$ dan asam folat yang banyak terkandung pada buah dan sayur. Mayoritas responden dalam penelitian ini mengkonsumsi susu dan teh pada saat pagi hari sebelum pergi ke kekelas

100.0

padahal menurut hasil penelitian Balci (2012) makanan yang dapat menghambat penyerapan zat besi yaitu kopi, coklat, teh dan kopi mengandung tanin yang dapat menghambat absorpsi zat besi. Susu juga merupakan pangan sumber protein yang baik yang memiliki bioavailabilitas tinggi.Protein yang terkandung di dalamnya berperan dalam distribusi zat gizi termasuk distribusi zat besi. Namun susu juga mengandung kalsium yang tinggi yang dapat menghambat penyeraban zat besi (Briawan, 2011). Asupan energi dalam penelitian ini menempati posisi tertinggi yaitu 13450 Kkal yang paling banyak dikonsumsi oleh responden yang anemia, padahal energi sangat baik sebagai zat pembangun akan tetapi daya absorbsi zat besi dari pangan karbohidrat yang diperoleh seagai sumber energi termasuk rendah sehingga tidak memberikan sumbangan zat besi dalam jumlah yang banyak (Misterianingtyas, 2009). Kekurangan konsumsi energi dapat menyebabkan anemi, hal ini terjadi karena pemecahan protein tidak lagi ditujukan untuk pembentukan sel darah merah dengan sendirinya menjadi kurang sehingga pemecahan protein energi dapat menyebabkan ketidakseimbangan dalam tubuh (Nursari 2010).

Selain itu, protein merupakan zat gizi kedua terkecil setelah karbohidrat yang dikonsumsi oleh santriwati Pondok Pesantren Al Masudiyah Puteri 2 Bleter Kab. Semarang yaitu sebanyak 1510 Kkal 
dengan jumlah siswi yang memenuhi kebutuhan proteinnya hanya sebanyak 20 siswi (24\%) sedangkan yang tidak memenuhi kebutuhan protein adalah sebanyak 62 siswi (76\%). Padahal menurut menurut Sunita Almatsier (2011), protein merupakan bagian dari semua sel hidup dan bagian terbesar pada tubuh sesudah air. Fungsi khas yang dimiliki adalah membangun serta memelihara sel- sel dan jaringan tubuh. Protein biasa dikonsumsi dari sumber lauk pauk, susu dan olahannya, buah serta sayur sehingga sangat penting dikonsumsi oleh tubuh. Mutu protein ditentukan oleh jenis dan proporsi asam amino yang dikandungnya. Protein komplet atau dengan nilai biologi tinggi atau bermutu tinggi adalah protein yang mengandung semua jenis asam amino esensial dalam proporsi yang sesuai untuk pertumbuhan. Protein berfungsi dalam pembentukan ikatan-ikatan esensial tubuh.Hemoglobin, pigmen darah yang berwarna merah berfungsi sebagai pengangkut oksigen dan karbondioksida adalah ikatan protein. Protein juga berperan dalam proses pengangkutan zat-zat gizi termasuk besi dari saluran cerna kedalam darah, dari darah kejaringan-jaringan, dan melalui membrane sel kedalam sel-sel, sehingga apabila kekurangan protein akan menyebabkan gangguan dalam absorpsi dan transportasi zat-zat gizi (Almatsier, 2009).

Semua protein hewani, kecuali gelatin, merupakan protein komplet. Protein tidak komplet atau protein bermutu rendah adalah protein yang tidak mengandung atau mengandung dalam jumlah kurang satu atau lebih asam amino esensial. Jenis protein yang dikonsumsi siswi adalah tahu dan tempe goreng yang mana padahal menurut Almatsier (2010) Sebagian besar protein nabati kecuali kacang kedelai dan kacang-kacangan lain merupakan protein tidak komplet. Selain itu konsumsi zat besi menempati posisi ketiga terendah yaitu sebanyak 1468 dibandingkan dengan jumlah konsumsi zat gizi lainnya.Ketidakcukupan jumlah Fe dalam makanan terjadi karena pola konsumsi makan masyarakat Indonesia masih didominasi sayuran sebagai sumber zat besi yang sulit diserap, sedangkan daging dan bahan pangan hewani sebagai sumber zat besi yang baik (heme iron) jarang dikonsumsi terutama oleh masyarakat pedesaan (Depkes RI, 1998).

Kurangnya pengetahuan tentang gizi dan kesehatan di Pondok Pesantren Al Masudiyah Puteri 2 Bleter Kab. Semarang merupakan salah satu faktor penyebab santriwati tidak mengatur pola makan mereka secara mandiri, hal ini sejalan dengan penelitian yang dilakukan oleh Handayani (2010) menyatakan bahwa tingkat pendidikan yang dicapai seseorang mempunyai hubungan nyata dengan pengetahuan gizi dari makanan yang dikosumsinya. Pengetahuan gizi dan kesehatan merupakan salah satu jenis pengetahuan yang dapat diperoleh melalui pendidikan. Pengetahuan gizi dan kesehatan akan berpengaruh terhadap pola konsumsi pangan. Semakin banyak pengetahuan tentang gizi dan kesehatan, maka semakin beragam pula jenis makanan yang dikonsumsi sehingga dapat memenuhi kecukupan gizi dan mempertahankan kesehatan individu (Suhardjo, 2011). 
Tabel 3. Distribusi frekuensi status hemoglobin pada santriwati Pondok Pesantren Al masudiyah Puteri 2 Bleter Kabupaten Semarang.

\begin{tabular}{lr}
\hline Status anemia & Freku \\
\hline Tidak anemia & 26 \\
Anemia & 56 \\
\hline Total & $\mathbf{8 2}$ \\
\hline & \\
\multicolumn{1}{c}{ Berdasarkan } & hasil penenlitian
\end{tabular}

dari 82 responden yang diperiksa, 56 $(68.3 \%)$ diantaranyamengalami anemia dan $26(31.7 \%)$ responden yang tidakmengalami anemia. Dalam penentuan status hemoglobin seseorang dapat dilakukan dengan berbagai metode, dan dalam penelitian ini pengukuran dilakukan dengan menggunakan metode dengan pengukuran menggunakan hemometer digital dan berdasarkan standar yang telah ditetapkan oleh WHO sebagai parameter yang digunakan untuk menetapkan status anemia. Prevalensi anemia ditemukan sebesar $68.3 \%$ dari 82 responden yang diperiksa. Angka yang didapatkan cukup mencengangkan dan sudah termasuk dalam golongan masalah kesehatan masyarakat yang moderat. Artinya masalah anemia ini harus segera ditangani dengan baik mengingat hemoglobin merupakan komponen utama eritrosit yang berfungsi membawa oksigen dan karbondioksi dan yang menjadi parameter yang digunakan untuk menetapkan prevalensi anemia.

Secara umum tingginya prevalensi anemia disebabkan oleh beberapa faktor diantaranya rendahnya asupan zat besi dan zat gizi lainnya seperti vitamin $\mathrm{A}$, vitamin $\mathrm{C}$, folat, riboplafin dan B12 (Briawan, 2014). Jika perempuan mengalami anemia akan sangat berbahaya pada waktu hamil dan melahirkan. Perempuan yang menderita anemia akan berpotensi melahirkan bayi dengan berat badan rendah (Rajab, 2009). Selain itu anemia pada remaja dapat menyebabkan
Persentase (\%)

31.7

68.3

keterlambatan pertumbuhan fisik, gangguan perilaku serta emosional (Sayoga, 2006). Berdasarkan hasil penelitian responden yang memiliki status anemia ada 48 siswi (87\%) dari 55 siswi yang mengalami anemia masuk kedalam kategori pola makan yang tidak memenuhi angka kecukupan gizi. Siswi yang mengalami anemia disebabkan oleh beberapa faktor diantaranya kebiasaan makan. Menurut Arisman (2004) menjelaskan bahwa kebiasaan makan merupakan cara seseorang dalam memilih makanan dan memakannya sebagai reaksi terhadap pengaruh psikologis, fisiologi, budaya dan sosial.Anemia merupakan kelanjutan dampak kekurangan zat gizi makro dan zat gizi mikro.Sedangkan dampak anemia pada remaja putri yaitu pertumbuhan terhambat, tubuh pada masa pertumbuhan mudah terinfeksi, mengakibatkan kebugaran/kesegaran tubuh berkurang, semangat belajar atau prestasi menurun.Hal ini sejalan dengan penelitian yang dilakukan oleh More (2013) bahwa anemia menyebabkan penurunan skor kognitif pada siswa. Selain itu, menurut Barasi (2009), rendahnya kadar hemoglobin mengakibatkan anemia dengan gejala pucat, lesu/lelah, sesak nafas dan kurang nafsu makan serta gangguan pertumbuhan (Barasi, 2009).

Analisis Bivariat

Gambaran hubungan antara pola makan dengan status anemia pada santriwati Pondok Pesantren $\mathrm{Al}$ masudiyah Puteri 2 Bleter Kabupaten Semarang. 
Tabel 4. Hubungan antara pola makan dengan status hemoglobin pada santriwati Pondok Pesantren Al masudiyah Puteri 2 Bleter Kabupaten Semarang.

\begin{tabular}{llllllll}
\hline \multirow{2}{*}{ Pola Makan } & \multicolumn{9}{c}{ Status Hemoglobin } \\
\cline { 2 - 8 } & \multicolumn{2}{c}{ Anemia } & \multicolumn{2}{c}{ Tidak Anemia } & Total & P \\
\cline { 2 - 8 } & F & \% & F & \% & F & \% & \\
\hline Normal & 8 & 34.8 & 15 & 65.2 & 23 & 100.0 & 0,001 \\
Defisit Ringan & 39 & 83.0 & 8 & 17.0 & 47 & 100.0 & \\
Defisit Berat & 8 & 80.0 & 2 & 20.0 & 10 & 100.0 & \\
Berlebih & 1 & 50.0 & 1 & 50.0 & 2 & 100.0 & \\
\hline Jumlah & $\mathbf{5 6}$ & $\mathbf{6 7 . 1}$ & $\mathbf{2 6}$ & $\mathbf{3 2 . 9}$ & $\mathbf{8 2}$ & $\mathbf{1 0 0 . 0}$ & \\
\hline
\end{tabular}

Tabel 4 menunjukan bahwa sebagian besar responden yang pola makannya normal mengalami anemia sebanyak $\quad 8$ responden (34.8\%).responden yang pola makannya defisit ringan mengalami anemia sebanyak 39 responden $(83.0 \%)$, responden yang pola makannya defisit berat mengalami anemia sebanyak 8 responden $(80.0 \%)$, Sedangkan responden yang pola makannya berlebih mengalami anemia sebanyak 1 responden $(50.0 \%)$.

Berdasarkan hasil uji kendall's tau dapat diketahui bahwa nilai $\mathrm{p}=0,001$, artinya terdapat hubungan antara pola makan dengan status anemia pada santriwati Pondok Pesantren Al masudiyah Puteri 2 Bleter. Hal ini sejalan dengan penelitian Fajriah (2015) bahwa berdasarkan hasil analisa ada hubungan yang signifikan antara pola makan dengan kejadian anemia pada remaja putri dengan nilai p-value $0,0000<0,05$. Demikian pula dengan hasil penelitian Herlina et al,. (2008) yang melaporkan bahwa semakin kurang baik pola makan, maka semakin tinggi angka kejadian anemia pada remaja, dan hal ini menunjukkan kebermaknaan secara statistik ( $\mathrm{p}$ < 0.05). Didukung oleh hasil penelitian yang dilakukan oleh Kurnia (2014), didapat bahwa hasil analisis data hubungan asupan makanan dengan kejadian anemia diperoleh taraf signifikan $\rho=0,000 \quad(\alpha=0,05)$ yang artinya asupan makanan mempengaruhi kejadian anemia siswi boga kelas XI Sekolah Menengah Kejuruan di SMKN 1 Buduran Sidoarjo.

Dari hasil penelitian responden yang memiliki status anemia ada 48 siswi (87\%) dari 55 siswi yang mengalami anemia masuk kedalam kategori pola makan yang tidak memenuhi angka kecukupan gizi dan tidak seimbang. Padahal makan makanan secara benar dan dengan gizi seimbang akan memberikan energi yang cukup, sebaliknya jika makan makanan secara tidak benar dan dengan gizi tidak seimbang maka akan berakibat menurunnya kemampuan otak, dan menurunnya semangat atau suasana hati pada tubuh.Berdasarkan hasil penelitian yang dilakukan oleh Mutiara (2017) prevalensi risiko apabila pola makan seseorang tidak baik (tidak mengkonsumsi salah satu antara karbohidrat, protein dan vitamin setiap kali makan) maka mempunyai risiko terjadinya anemia 1,600 kali lebih besar dibandingan seseorang yang pola makannya baik (mengkonsumsi karbohidrat, protein dan vitamin setiap kali makan). Berdasarkan hasil penelitian yang dilakukan peneliti sejalan dengan hasil penelitian Siahaan (2012) yaitu hasil uji statistik menunjukkan terdapat hubungan yang bermakna antara pola konsumsi yang baik (asupan protein dan sayuran hijau) dengan kejadian anemia pada remaja putri (p-value 0,05). Hal ini sejalan 
dengan penelitian yang dilakukan oleh Chaturvedi et al (2017) bahwa remaja yang tidak mengkonsumsi sayuran hijau akan memiliki peluang lebih besar menderita anemia dibandingkan dengan remaja yang mengkonsumsi sayuran. Menurut Fatimah St et al., (2011) diantara berbagai faktor penyebab terjadinya anemia, pola makan merupakan faktor yang paling dominan (50\%) pengaruhnya terhadap anemia.hal ini dibuktikan oleh penelitian yang dilakukan Nurbaiti (2011) menyatakan bahwa ada hubungan antara pola makandengan kejadian anemia remaja putri di SMA Negeri 11 Banda Aceh tahun 2013 dengan nilai $p$ value 0,001 .

Kurangnya asupan gizi seperti lauk pauk dan jumlah zat gizi dalam sekali makan serta porsi yang sama rata menjadi salah satu masalah dalam pemenuhan zat gizi individu, makanan yang disediakan oleh guru yang terbatas mengakibatkan siswi harus bisa memenuhi sendiri kebutuhan zat gizi mengingat kebutuhan zat gizi dalam satu kali makan belum cukup untuk memenuhi angka kecukupan gizi individu. Menurut Citrakesumasari, (2012) Seseorang yang banyak makan nasi, tetapi kurang makan sayursayuran serta buah-buahan dan laukpauk, akan tetap menjadi anemia walaupun zat besi yang dikonsumsi dari makanan sehari-hari cukup banyak .

Kecukupan akan zat gizi sangat diperlukan oleh setiap individu sejak dalam kandungan, bayi, anak-anak, masa remaja hingga usia lanjut melalui pemenuhan kebutuhan zat gizi individu,berdasarkan penelitian yang dilakukan Fatma (2010), di Negara Bangladesh sekitar $43 \%$ remaja putri di desa menderita anemia. Lebih dari $50 \%$ remaja putri di daerah tersebut mengalami stunted. Penyebab terjadinya hal tersebut karena rendahnya status gizi remaja putri karena diskriminasi gender, rendahnya tingkat pendidikan, kemiskinan, pemberian makanan yang tidak memadai, pantangan terhadap jenis makanan tertentu, kepercayaan, dan distribusi makanan dalam keluarga tidak merata Gizi merupakan salah satu faktor penentu kualitas sumber daya manusia. Anemia yang terjadi pada remaja berdampak pada terhambatnya mental dan kecerdasan serta menurunnya konsentrasi dan semangat belajar Ahmadi (2016). Begitu besar dampak anemia pada remaja putri yaitu pertumbuhan terhambat, tubuh pada masa pertumbuhan mudah terinfeksi, mengakibatkan kebugaran/kesegaran tubuh berkurang, semangat belajar atau prestasi menurun. Hal ini sejalan dengan penelitian yang dilakukan oleh More (2013) bahwa anemia menyebabkan penurunan skor kognitif pada siswa.

Salah satu pendekatan intervensi gizi remaja dalam menanggulangi kejadian anemia adalah menggunakan lingkungan sekolah. Bentuk intervensi yaitu dengan pemberian suplementasi $\mathrm{Fe}$, kapsul vitamin A, kapsul iodium, pendidikan gizi, dan sosialisasi konsumsi makanan yang difortifikasi. Intervensi fortifikasi makanan dengan zat gizi mikro harus diintegrasikan dengan intervensi hygiene sanitasi dan penyakit infeksi sehingga masalahnya dapat teratasi dengan baik (Fatmah, 2010).

Mengingat pentingnya memperhatikan makanan pada setiap individu dalam memenuhi kebutuhan tubuh maka perlu kesadaran pada diri sendiri, hal ini sesuai dengan Al-Quran dalam surat Abasa ayat 24 berbunyi: "Maka hendaklah manusia itu memperhatikan makanannya".

\section{KESIMPULAN DAN SARAN Kesimpulan}

1. Pola makan santriwati Pondok Pesantren Al Masudiyah Puteri 2 Bleter 
Kabupaten Semarang sebagian besar dalam kategori ringan yaitu sebanyak 47 responden $(57,3 \%)$, kategori normal sebanyak 23 responden (28\%), kategori defisit berat sebanyak 10 responden $(12,2 \%)$, dan berlebih sebanyak 2 responden $(2,4 \%)$.

2. Kejadian anemia setelah dilakukan pemeriksaan bahwa sebagian besar santriwati Pondok Pesantren Al Masudiyah Puteri 2 Bleter Kabupaten Semarang mengalami anemia sebanyak 55 responden $(67.1 \%)$.

3. Ada hubungan antara pola makan dengan kejadian anemia pada santriwati Pondok Pesantren Al masudiyah Puteri 2 Bleter dengan $\mathrm{p}$ value $=0,001$

\section{Saran}

Bagi remaja puteri yang anemia

Hendaknya hasil pemeriksaan dan informasi yang diberikan oleh peneliti dapat menjadi bekal remaja untuk lebih memperhatikan pola makan demi kehidupan yang lebih sehat.

Bagi institusi pendidikan

Diharapkan dapat menjadi informasi, bahan bacaan untuk menambah khasanah ilmu pengetahuan dan menjadi sumber informasi bagi penelitian selanjutnya yang dapat dimanfaatkan oleh mahasiswa diperpustakaan khususnya tentang anemia dan pola makan remaja.

$$
\text { Bagi tempat penelitian }
$$

Hendaknya pihak sekolah memperhatikan pola makan siswi untuk memberikan makanan sesuai dengan pola makan seimbang yaitu 3 kali makan utama dan 2 kali makan selingan sesuai dengan pola makan seimbang untuk memenuhi kecukupan gizi siswi. Hendaknya pihak sekolah meningkatkan kerjasama dengan pihak lain seperti Puskesmas ataupun tenaga kesehatan lain untuk melakukan penyuluhan dan pendidikan kesehatan guna menambah pengetahuan remaja tentang pentingnya memperhatikan pola makan yang baik.

Bagi instansi pelayanan kesehatan hendaknya pihak instansi pelayanan kesehatan terkait meningkatkan pelayanan kesehatan pada program yang sudah ada salah satunya adalah pendidikan kesehatan pada remaja berkaitan dengan anemia dan fortifikasi zat besi ke sekolah secara continue dan berkesinambungan.

\section{DAFTAR PUSTAKA}

Ari Istiany dan Rusilanti. (2013). Gizi terapan. PT Remaja Rosdakarya: Bandung Arisman. 2009. Gizi Dalam Daur Kehidupan. Buku Ajar Ilmu Gizi.EGC: Jakarta. Almatsier, S. 2009. Prinsip Dasar Ilmu Gizi.Penerbit PT Gramedia Pustaka Utama: Jakarta.

Balci, YI., Karabulut, A, Gurses D, dan Covut,I.E. (2012). Prevalenceand Risk Factors of Anemia among Adolescents in Denizli Turkey. Iran J Pediatr.

Briawan, D. 2013. Anemia Masalah Gizi pada Remaja Wanita. EGC. Jakarta. Citrakesumasari.(2012). Anemia Gizi Masalah dan Pencegahannya. Kaliaka:Yogyakarta.

Dinkes, Jateng. (2013). Profil Kesehatan Provinsi Jawa Tengah Tahun 2012. Dinkes Jateng: Semarang.

Fajriah, L. 2015. Hubungan Pola Makan dengan Kejadian Anemia pada Remaja Putri. Skripsi : Semarang

Hayati, RM. (2010). Pengetahuan dan Sikap Anemia Defisiensi Besidan Dampaknya 
terhadapKesehatan Reproduksi di IAIN Medan Tahun 2009/2010.Universitas

SumateraUtara: Medan.

Handayani IS, (2008). Hubungan Antara Sosial Ekonomi Keluarga dengan Status Gizi Balita Indonesia. Skripsi IPB: Bogor.

Istiany, Ari danRusilanti. (2013). Gizi Terapan. Remaja Rosdakarya: Jakarta. Kementerian Kesehatan RI. 2013. Pedoman Umum Gizi Seimbang. Jakarta.

Nursari, D. (2010). Gambaran Kejadian Anemia Pada RemajaPutri SMP Negeri 18 Kota Bogor Tahun 2009.UIN Syarif Hidayatullah: Bogor.

Rajab, Wahyudin. (2009). Buku Ajar Epidemiologi Untuk Mahasiswa Kebidanan. Jakarta : EGC.

Sayogo, S. (2006). Gizi Remaja Putri. Jakarta : EGC.

Siahaan, N.R. (2012). Faktor-faktor yang Berhubungan dengan Status Anemia pada Remaja Putri di Wilayah Kota Depok Tahun 2011. Skripsi. UI. Depok.

Tim Penulis Poltekkes Depkes Jakarta I. (2010). Kesehatan Remaja Problem dan Solusinya. Salemba Medika: Jakarta.

WHO. (2013). About Cardiovascular diseases. World Health Organization. Geneva. Cited July 15th2014. Available from URL : http://www.who.int/cardiovascul ar_diseases/about_cvd/en/ accessed on. 